all of volcanic origin, left relatively bare after the glacial periods and the home of wide-ranging oceanic birds.

\section{E. J. Godley}

Botany Division,

Department of Scientific and Industrial Research,

Christchurch,

New Zealand.

Received February 6; revised Eebruary 27, 1967.

${ }^{1}$ Melville, R., Nature, 211, 116 (1966).

${ }^{2}$ Schenck, H., Deut. Süd-Polar Exped., 8, 97 (1906).

${ }^{3}$ (Chastain, A., Mem. Mus. Nat., Series B., Bot., 11 (Paris, 1958).

"Schimper, A. F. W., in Schenk, H., Wiss. Ergebn. Deut. Tiefsee-Exped., 2, $63(1905)$

s Ridley, H. N., The Dispersal of Plants Throughout the World (Reeve and Co., Kent, 1930).

' (iuppy. H. B., Observations of a Naturalist in the Pacific, 2, Plant Dispersal (Macmillan and Co., London, 1906).

skottsberg, C., Wiss. Ergebn. Schwed. Süd-Polar Exped., 1901-1903, 4 3 (1905).

8 ('heeseman, T. F., Australasian Ant. Exped., Series C., 7 (1919).

${ }^{9}$ Taylor, B. W., Rep. A ustral. Nat. Antarct. Res. Exped., Series B., 2 (1955).

10 Cheeseman, T. F., in The Subantarctic Islands of New Zealand, 2, 389 (Government Printer, Wellington, 1909).

$"$ Moore, L. B., in Allan, H. H., Flora of New Zeuland (Government Printer, Wellington, 1961).

${ }^{12}$ (iodley, E. J., Rev. Univ. Santiago (1963).

${ }^{13}$ Skottsberg, C., Bot. Ergebn. Schwed., Exped. nach Patagonien und dem Feuerlande, 1907-1909, 5 (1916).

${ }^{14}$ Frankel, O. H., and Hair, J. B., N.Z. J. Sci. Tech., 18, 669 (1937).

${ }_{15}$ Oliver, W. R. B., New Zealand Birds (A. H. and A. W. Reed, Wellington, $1955)$.

${ }^{16}$ Falla, R. A., Proc. Roy. Soc., B, 152, 655 (1960).

\section{PHYSICS}

\section{High Gain Pulsed Laser}

THIs communication reports the finding of a super radiant transition at $\lambda=1.793 \mu \mathrm{m}$. Three lines have been observed botween $1.27 \mu \mathrm{m}$ and $2.4 \mu \mathrm{m}$, and these are assumed to be due to the transitions listed in Table 1 .

$\begin{array}{cc} & \text { Table 1 } \\ \lambda(\mu \mathrm{m}) & \text { Transition } \\ 1.270 & \text { Argon I 3 } d_{2}-2 P_{6} \\ 1.793 & \text { Argon I 3d }-2 P_{6} \\ 2.397 & \text { Argon I } 3 d_{6}-2 P_{2}\end{array}$

Thu tube used in these experiments is $1.5 \mathrm{~m}$ long and $2.5 \mathrm{~cm}$ in diameter, made of silica, with optically sealed Brewster angle windows. The tube is normally filled with a helium-neon mixture and is excited by means of external electrodes to which are applied $0.5 \mu$ sec pulses of high voltage, as described by H. A. H. Boot et al. ${ }^{1}$.

The helium-neon mixture gives, as is well known, a strong line at $\lambda=1.15 \mu \mathrm{m}$. There is, however, a marked saturation in output power with increasing input power. In an attempt to overcome the output saturation, a small amount of argon was added to the helium-neon mixture. The addition of small amounts of argon was initially proposed to reduce the radiation trapping effects of neon metastables by a collision process. It has been found experimentally that the addition of argon changes the operating wavelength from $1.15 \mu \mathrm{m}$ to $1.79 \mu \mathrm{m}$. The gain under these conditions is sufficiently high to allow super radiant operation.

At a pulse repetition frequency of (l kc/s) $\mathrm{l} k \mathrm{kHz}$ a peak output power of $50 \mathrm{~W}$ has been measured with a single plane mirror coated in aluminium. A laser cavity formed by the addition of a plane uncoated optical flat as the output mirror gives a power of $72 \mathrm{~W}$.

Tentative measurements of beam divergence using a single mirror give a figure of $7 \cdot 3$ mradians.

Single pass gain measurements have been made using a mirror coated with aluminium with an assumed reflec- tivity of 90 per cent. This gave a gain of $10 \cdot 5 \mathrm{~dB} /$ metre or the $1 \cdot 79 \mu \mathrm{m}$ transition.

\section{A. D. BRISBANE}

Standard Telecommunications Laboratory,

Harlow,

Essex.

Received February 24, 1967.

${ }^{1}$ Boot, H. A. H., Clunie, D. M., and Thorn, R. S. A., Nature, 198, 773 (1963).

\section{Reduction of Audible Flame Noise by the Application of Ultrasonics}

As early as 1858 , Leconte $^{1}$ pointed out that the character and appearance of ignited gas jets were altered when subjected to small amounts of discrete acoustic frequencies. An early study of these "sensitive flames" 2 showed, however, that the sensitivity of the jet was essentially independent of the combustion process. Most subsequent investigations ${ }^{3,4}$ have been concerned with unignited jets. In general it has been shown that the disturbances generated by acoustic waves directed across the top of the jet orifice grow to form vortices which are shed downstream from the nozzle on either side of the unignited jet.

Our experiments show that the application of acoustic energy transversely to ignited jets of town gas produces a marked reduction in the audible output of noise ${ }^{5}$. This effect has been found to occur with applied frequencies of about $2 \mathrm{kc} / \mathrm{s}$ upwards and with ignited town-gas jets issuing, at Reynolds numbers of up to 4,000, from 'Amal' nozzles. At ultrasonic frequencies of the order of $40 \mathrm{kc} / \mathrm{s}$ reductions of about $6 \mathrm{~dB}$ (standard " $A$ " weighting ${ }^{6}$ ) in the total audible output have been observed. The change was produced by an applied field of $100 \mathrm{~dB}$ sound pressure level at the nozzle orifice, generated by an energy input of $20 \mathrm{~mW}$ to the barium titanate transducer. This was less than 0.01 per cent of the heat energy released by the flame.

As shown in Fig. 1, the acoustic field has the effect of slightly shortening and broadening the flame, while near the nozzle an intensification in the emission of blue light-indicating a stabilizing effect-was observed. Shadowgraphs of the ignited jet taken in the presence of the acoustic field also showed that the jet core tip oscillated at a relatively low frequency (Fig. 2).

We have also found that the audible noise generated by unignited jets can be reduced in a similar manner. Further experiments with both aerated and non-aerated Bunsen burner flames showed that significant reductions in noise could be obtained.

These results clearly show that it is possible to influence appreciably the flow pattern of an issuing jet with small
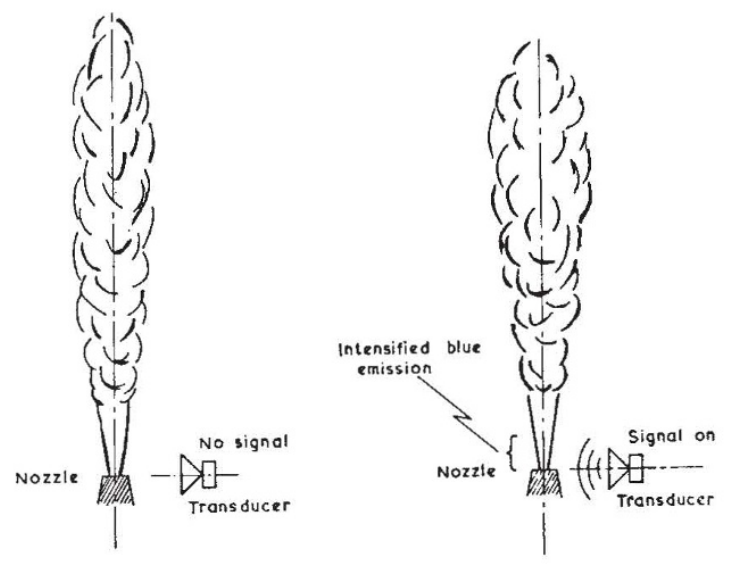

Fig. 1. Effect of an acoustic field on flame appearance. 